Article

\title{
Axial Strength of Eccentrically Loaded FRP-Confined Short Concrete Columns
}

\author{
Cheng Jiang ${ }^{1,2}\left(\mathbb{D}\right.$ and $\mathrm{Yu}$-Fei $\mathrm{Wu}{ }^{1,3, *}$ \\ 1 School of Engineering, RMIT University, 376-392 Swanston St, Melbourne, VIC 3001, Australia \\ 2 Department of Civil and Environmental Engineering, The Hong Kong Polytechnic University, Hung Hom, \\ Kowloon 999077, Hong Kong, China; c.jiang@polyu.edu.hk \\ 3 Guangdong Provincial Key Laboratory of Durability for Marine Civil Engineering, Shenzhen University, \\ Shenzhen 518060, China \\ * Correspondence: yufei.wu@rmit.edu.au
}

Received: 24 April 2020; Accepted: 29 May 2020; Published: 31 May 2020

check for updates

\begin{abstract}
This paper presents an experimental program that includes 78 fiber reinforced polymer (FRP)-confined square concrete columns subjected to eccentric loading. The degradation of the axial strength of FRP-confined short concrete columns due to the load eccentricity is investigated in this work. A larger load eccentricity leads to a greater decrease in the axial strength. From the test results, it is found that FRP confinement can cause less strength degradation compared with that of unconfined concrete specimens. For FRP-confined square concrete specimens, the strength enhancement due to FRP confinement increases with increasing load eccentricity. However, the increasing load eccentricity decreases the confinement efficiency for FRP-confined circular concrete specimens. The relationship between the strength of eccentrically loaded FRP-confined square columns and their corner radii is evaluated.
\end{abstract}

Keywords: FRP; concrete; confinement; eccentric load; axial strength; column

\section{Introduction}

Fiber reinforced polymer (FRP) jacketing or confinement has been widely adopted and used in rehabilitation work on concrete structures [1-4]. The confinement can not only enhance the strength and ductility of a concrete structure [5,6] but also increase the bond between the concrete and internal steel reinforcement [7-9]. In addition to the structural rehabilitation, the concept of FRP confinement has also been adopted in the constructions of new structures, such as the applications of concrete filled FRP tubes [10-12]. Various models for concrete columns strengthened with FRPs under concentric loading have been proposed in the past three decades. These stress-strain and strength models have covered different sections of circular (e.g., [13-19]), square (e.g., [20,21]), rectangular (e.g., [22-24]), and cross-sectional unified (e.g., [25-27]) types. In practical engineering applications, most existing concrete columns with noncircular cross-sections are subjected to eccentricity loading. However, concentrically loaded models have usually been used to analyze cases with eccentrically loading. It is well established in the literature that the load eccentricity affects the confinement behavior of FRP jacketed concrete columns [28-31] because the eccentric loading causes a variation in the confinement pressure across the section, thereby leading to a stress state that differs from that under concentric loading for a certain axial strain.

Many experimental investigations on eccentrically loaded FRP confined columns have been carried out on circular columns [30,32-41] and noncircular columns [28,42-50]. Other investigations [29,31,51] focused on finite element modeling (FEM) to investigate the effect of the load eccentricity on FRP-confined concrete columns. It is found that the eccentric loading highly influences the mechanical behaviors 
of FRP-confined concrete. There is no doubt that the global response has a degradation trend due to load eccentricity. More recently, the effect of load eccentricity on the stress-strain relationship for cross-sectional analysis was deeply investigated and discussed. For example, Maaddaw [28] developed a simple theoretical stress-strain model considering load eccentricity, which has a reduction effect on the stress-strain relationship. However, other researchers found that load eccentricity enhanced the stress-strain behavior from both experimental [30] and numerical [31] analyses.

Overall, the available tests on eccentrically loaded FRP-confined concrete columns are limited in the open literature, especially for square cross-sections. As the confinement mechanism for square columns is different with that of circular columns, it is necessary to clearly understand the relationship between column section and confinement efficiency under eccentric loading. This work aims to investigate the degradation of the axial load capacity due to the load eccentricity on FRP-confined square and circular short concrete.

\section{Experimental Program}

The experimental program included 78 square confined columns with different FRP confinements (32 specimens without confinement, 32 specimens with 1-ply FRP confinement, and 14 specimens with 2-ply FRP confinement), corner radius ratios (12 specimens with $15 \mathrm{~mm}, 42$ specimens with $30 \mathrm{~mm}$, 12 specimens with $45 \mathrm{~mm}$, and 12 specimens with $60 \mathrm{~mm}$ ), and a full range of load eccentricities (12 specimens each for $0,10,20,30,40$ and $50 \mathrm{~mm}$, and 6 specimens with $60 \mathrm{~mm}$ ). The details of the specimen design are given in Table 1. All the specimens were tested in the Heavy Structure Testing Laboratory in the City University of Hong Kong.

All the specimens were designed with a width of $150 \mathrm{~mm}(b)$, a depth of $150 \mathrm{~mm}(d)$ and a height of $300 \mathrm{~mm}$ with different corner radii $(r)$. To independently study the behaviors of the confined concrete, no internal reinforcement was used for the specimens. The corner radius ratio $\rho$ is a key factor that affects the confining effect of FRP wrapping and is determined as [25-27,52]:

$$
\rho=2 r / b
$$

where $b$ is the length of the side for square cross-sections and the diameter for circular sections. The effect of the corner radius ratio $\rho$ and the steel molds for concrete casting can be found in Figure 1 .

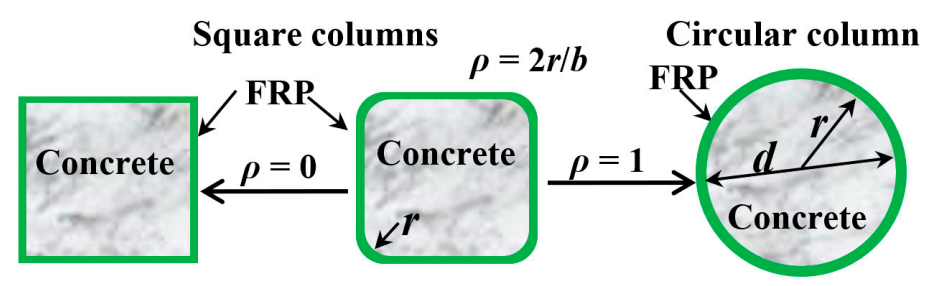

(a) Cross-sectional unification by the factor $\rho$

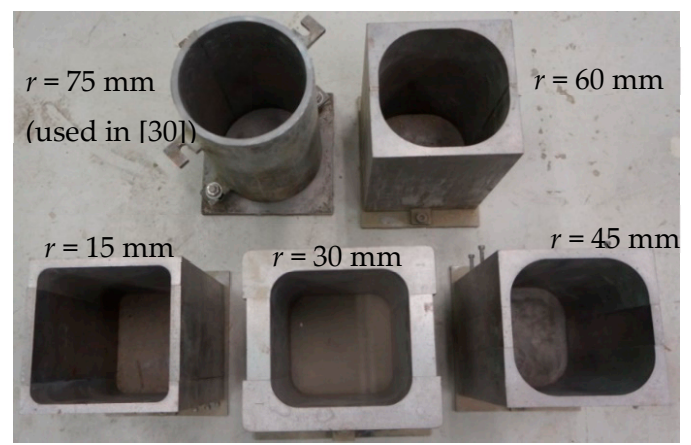

(b) Prefabricated steel molds with various corner radii

Figure 1. Cross-sections in this work: (a) Cross-sectional unification by the factor $\rho$; (b) Prefabricated steel molds with various corner radii. 
As the specimens in this work could not be cast with one single batch of concrete, they were carefully grouped to minimize the unavoidable differences caused by the variations between the concrete properties of different batches. Specimens with the same FRP layers but different load eccentricities were grouped in one batch. Hence, the variation in the eccentricity could be isolated from the variation due to other factors.

A carbon fiber reinforced polymer (CFRP) was used for the FRP wrapping, which had a nominal thickness of $0.167 \mathrm{~mm}$. A two-part Sikadur-300 was used as the saturant resin. Flat coupon tensile tests were conducted following ASTM D3039 [53] to determine the mechanical properties of the CFRP sheets. The ultimate strength, tensile modulus and ultimate strain of the CFRP sheets in this work were $4192 \mathrm{MPa}, 254 \mathrm{GPa}$, and 1.84\%, respectively. The CFRP sheets were wrapped around the specimens using the manual lay-up procedure in the hoop direction. Each CFRP jacket had a single overlap of $150 \mathrm{~mm}$ in length.

For the specimen IDs in Table 1, the number after the letter $\mathrm{R}$ represents the corner radius with units of mm; subsequently, the two identical specimens are separated into two different groups identified by the letter A or B in the specimen IDs for the specimens with $30 \mathrm{~mm}$ of corner radius; the second figure of specimen ID $(0,1$ or 2$)$ denotes the number of CFRP layers; and the remaining indicators, E0, E10, E20, E30, E40 or E50, represent a load eccentricity of 0, 10,20, 30, 40 and $50 \mathrm{~mm}$, respectively. For example, R45B2E30 indicates the FRP-confined square concrete specimen with a corner radius of $45 \mathrm{~mm}$ in group B, which was applied with 2-ply CFRP sheets and a load eccentricity of $30 \mathrm{~mm}$.

All the specimens were tested after 28 days of curing. The test setup is shown in Figure 2. Eccentric loading was applied by a knife edge at the top of the specimen (Figure 2). The specimen was placed on a flat and greased plate at the bottom so that friction at the end was minimized. The vertical displacements of the specimen at both the compression and tension sides were measured by two $50 \mathrm{~mm}$-travel linear variable differential transformers (LVDTs), which were mounted on an aluminum frame with a $200 \mathrm{~mm}$ gauge length in the middle. A total of $75 \mathrm{~mm}$ was left between the specimen surfaces and the LVDTs. The specimens were tested under monotonically increasing loading until failure, controlled with a displacement rate of approximately $0.3 \mathrm{~mm} / \mathrm{min}$. The load was measured by a load cell placed at the bottom of the specimen (Figure 2).

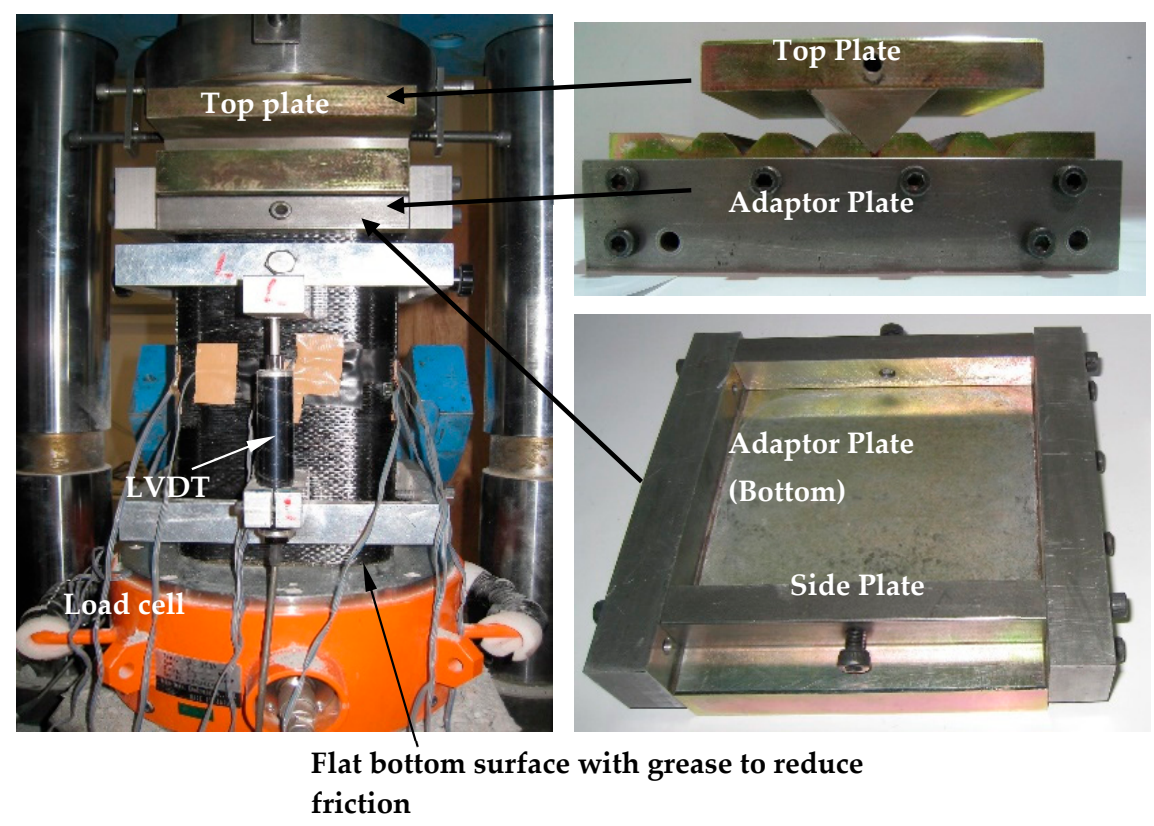

Figure 2. Test setup. 
Table 1. Details of the test specimens.

\begin{tabular}{|c|c|c|c|c|c|c|c|c|c|c|c|}
\hline $\begin{array}{l}\text { Specimen } \\
\text { ID }\end{array}$ & $\begin{array}{c}r \\
(\mathrm{~mm})\end{array}$ & $\begin{array}{c}f_{c o} \\
(\mathbf{M p a})\end{array}$ & $\begin{array}{c}e \\
(\mathrm{~mm})\end{array}$ & $\begin{array}{c}\text { FRP } \\
\text { Layers }\end{array}$ & $\begin{array}{c}N_{e} \\
(\mathbf{k N})\end{array}$ & $\begin{array}{l}\text { Specimen } \\
\text { ID }\end{array}$ & $\begin{array}{c}r \\
(\mathrm{~mm})\end{array}$ & $\begin{array}{c}f_{c o} \\
(\mathbf{M p a})\end{array}$ & $\begin{array}{c}e \\
(\mathrm{~mm})\end{array}$ & $\begin{array}{c}\text { FRP } \\
\text { Layers }\end{array}$ & $\begin{array}{c}N_{e} \\
(\mathbf{k N})\end{array}$ \\
\hline R15A0E0 & 15 & 25.6 & 0 & 0 & 571.8 & R30B0E60 & 30 & 35.4 & 60 & 0 & 184.9 \\
\hline R15A0E10 & 15 & 25.6 & 10 & 0 & 551.8 & R30B1E0 & 30 & 35.6 & 0 & 1 & 952.7 \\
\hline R15A0E20 & 15 & 25.6 & 20 & 0 & 483.8 & R30B1E10 & 30 & 35.6 & 10 & 1 & 878.7 \\
\hline R15A0E30 & 15 & 25.6 & 30 & 0 & 438.8 & R30B1E20 & 30 & 35.6 & 20 & 1 & 764.7 \\
\hline R15A0E40 & 15 & 25.6 & 40 & 0 & 383.8 & R30B1E30 & 30 & 35.6 & 30 & 1 & 802.7 \\
\hline R15A0E50 & 15 & 25.6 & 50 & 0 & 292.9 & R30B1E40 & 30 & 35.6 & 40 & 1 & 778.7 \\
\hline R15A1E0 & 15 & 30.9 & 0 & 1 & 826.7 & R30B1E50 & 30 & 35.6 & 50 & 1 & 493.8 \\
\hline R15A1E10 & 15 & 30.9 & 10 & 1 & 788.7 & R30B1E60 & 30 & 35.6 & 60 & 1 & 509.8 \\
\hline R15A1E20 & 15 & 30.9 & 20 & 1 & 732.7 & R30B2E0 & 30 & 40.7 & 0 & 2 & 1448.5 \\
\hline R15A1E30 & 15 & 30.9 & 30 & 1 & 665.8 & R30B2E10 & 30 & 40.7 & 10 & 2 & 1383.5 \\
\hline R15A1E40 & 15 & 30.9 & 40 & 1 & 589.8 & R30B2E20 & 30 & 40.7 & 20 & 2 & 1261.6 \\
\hline R15A1E50 & 15 & 30.9 & 50 & 1 & 487.8 & R30B2E30 & 30 & 40.7 & 30 & 2 & 1215.6 \\
\hline R30A0E0 & 30 & 35.4 & 0 & 0 & 753.7 & R30B2E40 & 30 & 40.7 & 40 & 2 & 1034.6 \\
\hline R30A0E10 & 30 & 35.4 & 10 & 0 & 671.7 & R30B2E50 & 30 & 40.7 & 50 & 2 & 858.7 \\
\hline R30A0E20 & 30 & 35.4 & 20 & 0 & 622.8 & R30B2E60 & 30 & 40.7 & 60 & 2 & 645.8 \\
\hline R30A0E30 & 30 & 35.4 & 30 & 0 & 523.8 & R45A0E0 & 45 & 26.8 & 0 & 0 & 555.8 \\
\hline R30A0E40 & 30 & 35.4 & 40 & 0 & 460.8 & R45A0E10 & 45 & 26.8 & 10 & 0 & 480.8 \\
\hline R30A0E50 & 30 & 35.4 & 50 & 0 & 336.8 & R45A0E20 & 45 & 26.8 & 20 & 0 & 452.8 \\
\hline R30A0E60 & 30 & 35.4 & 60 & 0 & 203.9 & R45A0E30 & 45 & 26.8 & 30 & 0 & 426.8 \\
\hline R30A1E0 & 30 & 35.6 & 0 & 1 & 950.7 & R45A0E40 & 45 & 26.8 & 40 & 0 & 359.8 \\
\hline R30A1E10 & 30 & 35.6 & 10 & 1 & 924.7 & R45A0E50 & 45 & 26.8 & 50 & 0 & 271.9 \\
\hline R30A1E20 & 30 & 35.6 & 20 & 1 & 886.7 & R45A1E0 & 45 & 36.1 & 0 & 1 & 997.7 \\
\hline R30A1E30 & 30 & 35.6 & 30 & 1 & 831.7 & R45A1E10 & 45 & 36.1 & 10 & 1 & 1003.6 \\
\hline R30A1E40 & 30 & 35.6 & 40 & 1 & 793.7 & R45A1E20 & 45 & 36.1 & 20 & 1 & 937.7 \\
\hline R30A1E50 & 30 & 35.6 & 50 & 1 & 447.8 & R45A1E30 & 45 & 36.1 & 30 & 1 & 816.7 \\
\hline R30A1E60 & 30 & 35.6 & 60 & 1 & 411.8 & R45A1E40 & 45 & 36.1 & 40 & 1 & 729.7 \\
\hline R30A2E0 & 30 & 40.7 & 0 & 2 & 1420.5 & R45A1E50 & 45 & 36.1 & 50 & 1 & 617.8 \\
\hline R30A2E10 & 30 & 40.7 & 10 & 2 & 1308.6 & R60A0E0 & 60 & 27.6 & 0 & 0 & 534.8 \\
\hline R30A2E20 & 30 & 40.7 & 20 & 2 & 1177.6 & R60A0E10 & 60 & 27.6 & 10 & 0 & 497.8 \\
\hline R30A2E30 & 30 & 40.7 & 30 & 2 & 1086.6 & R60A0E20 & 60 & 27.6 & 20 & 0 & 412.8 \\
\hline R30A2E40 & 30 & 40.7 & 40 & 2 & 918.7 & R60A0E30 & 60 & 27.6 & 30 & 0 & 372.8 \\
\hline R30A2E50 & 30 & 40.7 & 50 & 2 & 591.8 & R60A0E40 & 60 & 27.6 & 40 & 0 & 306.9 \\
\hline R30A2E60 & 30 & 40.7 & 60 & 2 & 340.8 & R60A0E50 & 60 & 27.6 & 50 & 0 & 205.9 \\
\hline R30B0E0 & 30 & 35.4 & 0 & 0 & 782.7 & R60A1E0 & 60 & 36.8 & 0 & 1 & 1052.6 \\
\hline R30B0E10 & 30 & 35.4 & 10 & 0 & 677.7 & R60A1E10 & 60 & 36.8 & 10 & 1 & 1045.6 \\
\hline R30B0E20 & 30 & 35.4 & 20 & 0 & 541.8 & R60A1E20 & 60 & 36.8 & 20 & 1 & 999.7 \\
\hline R30B0E30 & 30 & 35.4 & 30 & 0 & 498.8 & R60A1E30 & 60 & 36.8 & 30 & 1 & 788.7 \\
\hline R30B0E40 & 30 & 35.4 & 40 & 0 & 398.8 & R60A1E40 & 60 & 36.8 & 40 & 1 & 703.7 \\
\hline R30B0E50 & 30 & 35.4 & 50 & 0 & 276.9 & R60A1E50 & 60 & 36.8 & 50 & 1 & 516.8 \\
\hline
\end{tabular}

Note: $r$ is the corner radius, $f_{c o}$ is the unconfined concrete strength, $e$ is the load eccentricity, and $N_{\mathrm{e}}$ is the axial load capacity (axial strength).

\section{Test Results and Discussion}

\subsection{Failure Modes and Cross-Sectional Strength}

For unconfined concrete specimens with concentric loading, the concrete mainly split longitudinally on the side surface, and the cone appearance could also be found on the failure surface. For unconfined columns with relatively larger load eccentricities, the failure of the specimens was generally marked by concrete crushing at the compression side at or near the mid-height of the specimen, and a horizontal crack at approximately mid-height or at the top of the column was clearly observed on the tensile side. For the columns with the largest eccentricity of $60 \mathrm{~mm}$, the specimens crushed at the top of the specimen on the compression side. The typical images of failure modes of the tested FRP-confined square short columns are shown in Figure 3. 

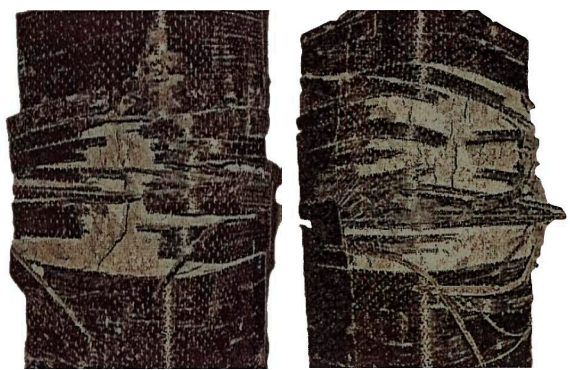

Figure 3. Typical failure mode.

The failure of all FRP-confined specimens was always caused by FRP rupture, and no delamination of the FRP at the overlapping zone was observed. Clicking sounds could be heard during the loading stage, and the failure occurred suddenly with an explosive sound. The fracture of the CFRP jacket was mainly near the corner of the compression side due to the stress concentration. On the tensile side, horizontal cracks along the fiber hoop direction were observed at mid-height or in adjacent areas. Furthermore, crushing of the concrete core occurred in the specimens with a relatively large load eccentricity. The test results for the axial strength, which refer to the peak load for a section in the tests $\left(N_{e}\right)$, of all the specimens are listed in Table 1. The typical load-displacement curves for eccentrically loaded FRP-confined square columns in this work and FRP-confined circular columns reported in [30] are illustrated in Figure 4. Each specimen in Figure 4 has two curves from two LVDTs on the compression side and tension side. Similarly to the circular columns, the degradation due to the load eccentricity is substantial, as observed in Figure 4. The sudden load loss or drop in the load-displacement curves indicates the occurrence of FRP rupture.

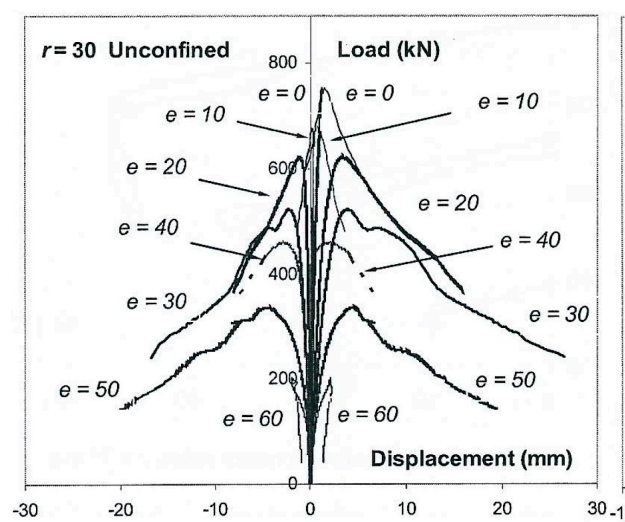

(a) $\rho=0.4$, unconfined, Group A

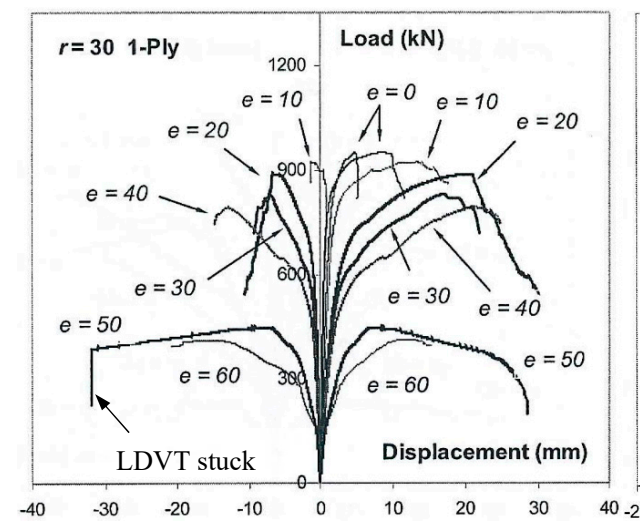

(c) $\rho=0.4$, 1-ply FRP, Group A

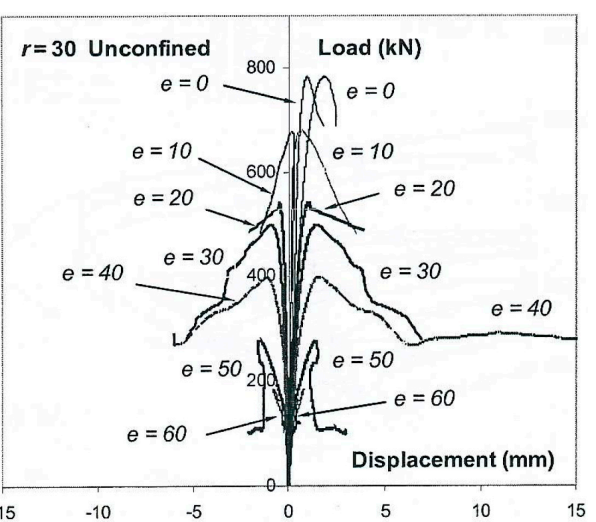

(b) $\rho=0.4$, unconfined, Group B

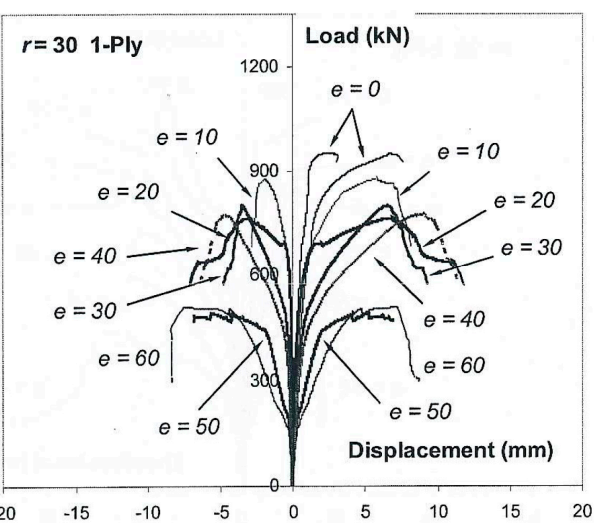

(d) $\rho=0.4$, 1-ply FRP, Group B

Figure 4. Cont. 


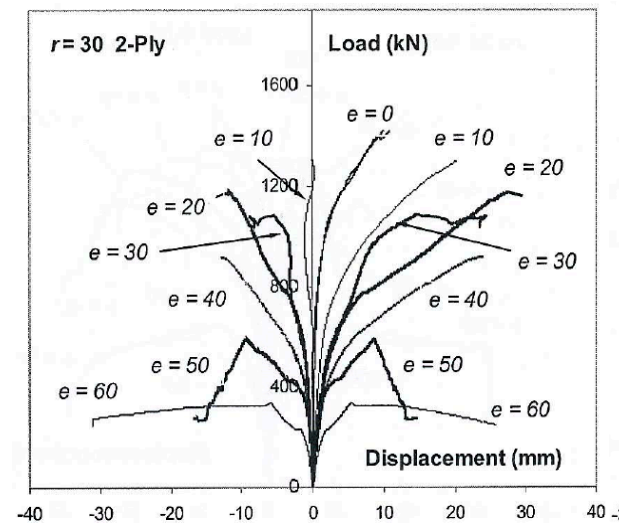

(e) $\rho=0.4$, 2-ply FRP, Group A

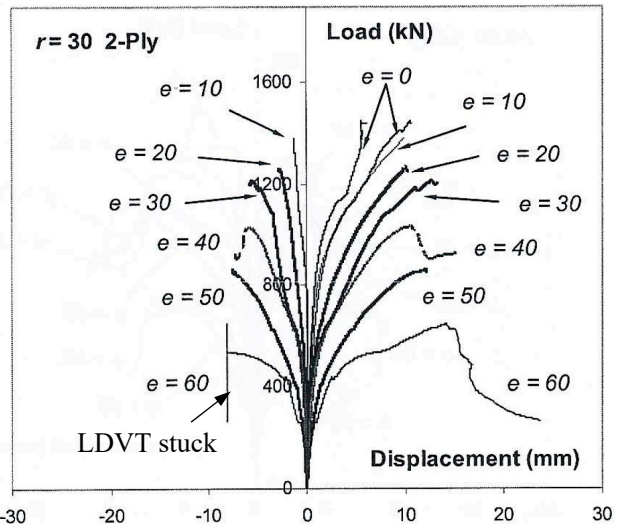

(f) $\rho=0.4$, 2-ply FRP, Group B

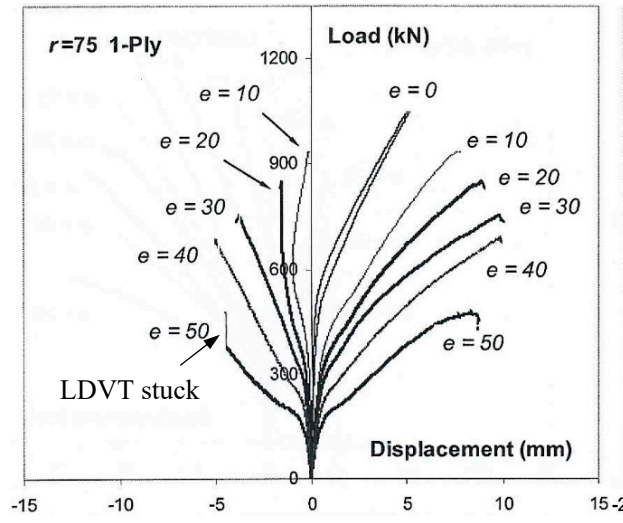

(g) $\rho=1$, 1-ply FRP, Group A in [30]

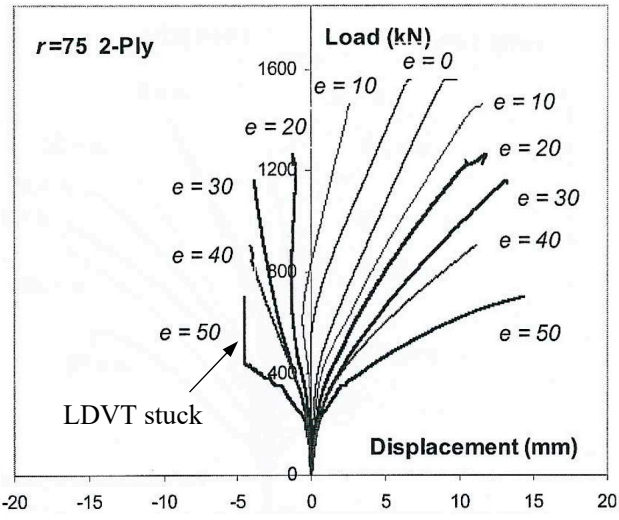

(h) $\rho=1$, 2-ply FRP, Group A in [30]

Figure 4. Typical load-deformation curves: (a) $\rho=0.4$, unconfined, Group A; (b) $\rho=0.4$, unconfined, Group B; (c) $\rho=0.4$, 1-ply FRP, Group A; (d) $\rho=0.4$, 1-ply FRP, Group B; (e) $\rho=0.4$, 2-ply FRP, Group A; (f) $\rho=0.4$, 2-ply FRP, Group B; (g) $\rho=1$, 1-ply FRP, Group A in [30]; (h) $\rho=1$, 2-ply FRP, Group A in [30].

\subsection{Effect of the Load Eccentricity and FRP Confinement}

The strength factor $N_{e} / N_{c 0}$ is defined and analyzed to study the effect of the load eccentricity on the degradation of the axial strength, where $N_{e}$ is the load capacity of the sections for FRP-confined concrete specimens with/without load eccentricity and $N_{c 0}$ is the load capacity for concentrically loaded unconfined concrete specimens. This type of load capacity comparison has been widely adopted in confined concrete analysis [54].

A nondimensionalized term $2 e / b$ is adopted to show the magnitude of the load eccentricity. By comparing the values of $N_{e} / N_{c 0}$, it is obvious that the axial strength decreases with increasing load eccentricity, as shown in Figure 5. When the eccentricity is small (e.g., $10 \mathrm{~mm}$ or $2 e / b=0.13$ ), the cross-sectional strength reduction degree is limited and is occasionally close to 0 . However, when the load eccentricity increases, the decrease in the axial strength is more significant. Additionally, a greater confinement (or number of FRP layers) results in a higher strength. 


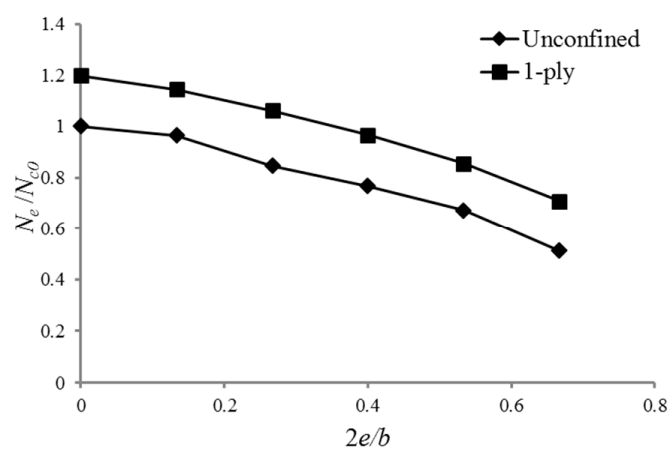

(a) $r=15 \mathrm{~mm}$

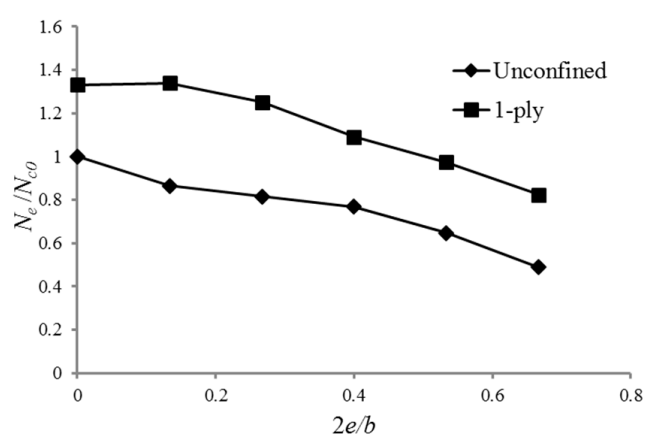

(c) $r=45 \mathrm{~mm}$

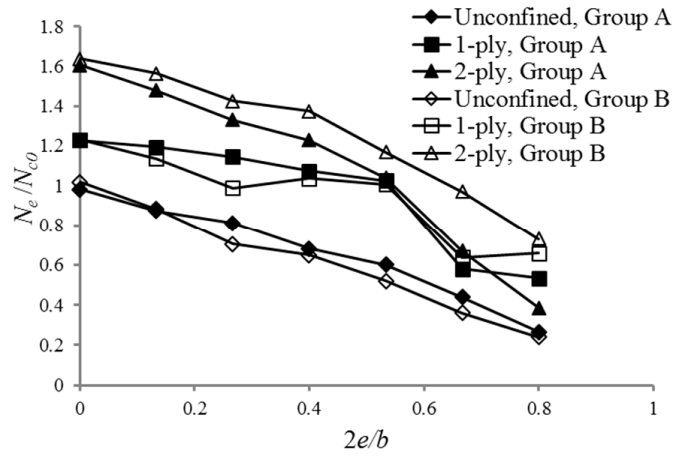

(b) $r=30 \mathrm{~mm}$

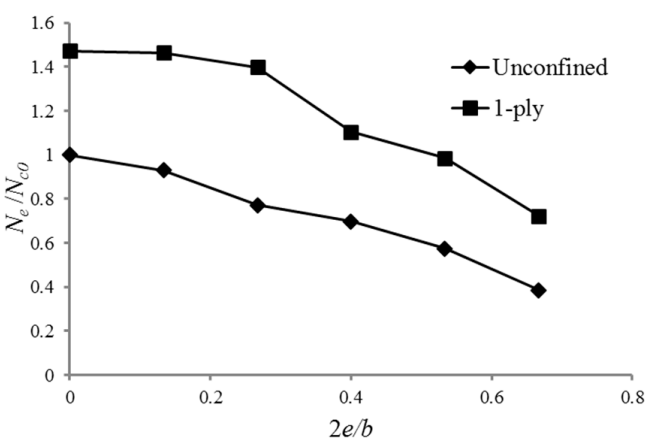

(d) $r=60 \mathrm{~mm}$

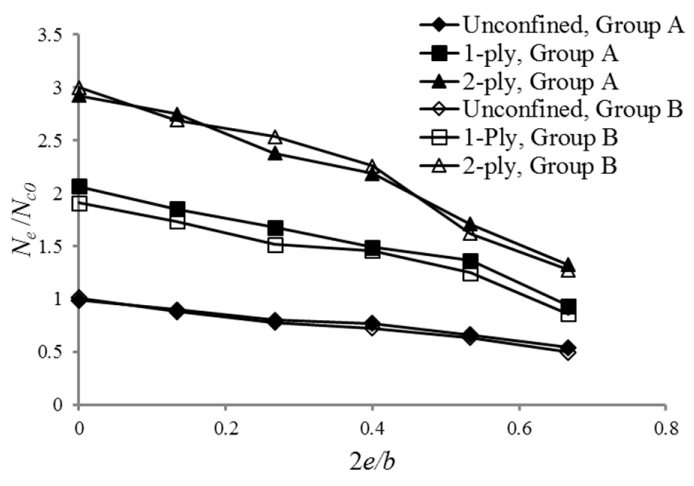

(e) $r=75 \mathrm{~mm}[30]$

Figure 5. Effect of the load eccentricity on $N_{e} / N_{c 0}$ : (a) $r=15 \mathrm{~mm}$; (b) $r=30 \mathrm{~mm}$; (c) $r=45 \mathrm{~mm}$; (d) $r=60 \mathrm{~mm}$; (e) $r=75 \mathrm{~mm}$ [30].

To better understand the strength degradation due to the load eccentricity, another comparison of $N_{e} / N_{c}$ is carried out by modifying the results in Figure 5 , where $N_{c}$ is the axial strength for concentrically loaded specimens with the same confinement level as that of $N_{e}$. The results are shown in Figure 6 . It can be concluded that the degradation of FRP-confined circular columns due to the load eccentricity (Figure 6e) is insensitive to the FRP confinement. However, for square columns (Figure 6a-d), FRP confinement can cause less axial strength degradation compared with that of unconfined concrete specimens. Different confinement levels (i.e., 1 layer and 2 layers) do not have a significant influence on the strength degradation, as can be observed in Figure $6 \mathrm{~b}$. 


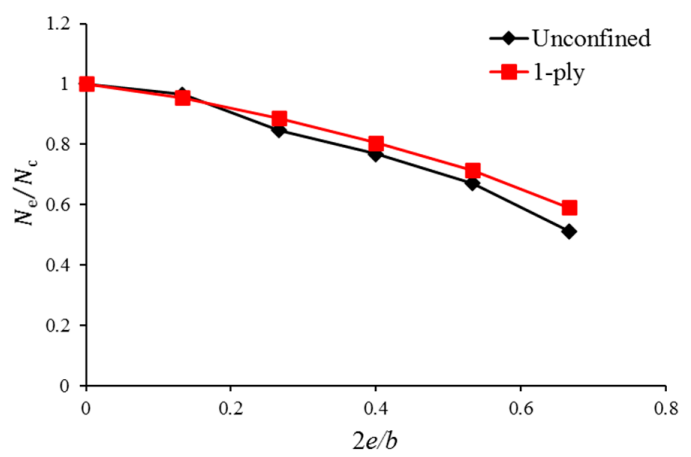

(a) $r=15 \mathrm{~mm}$

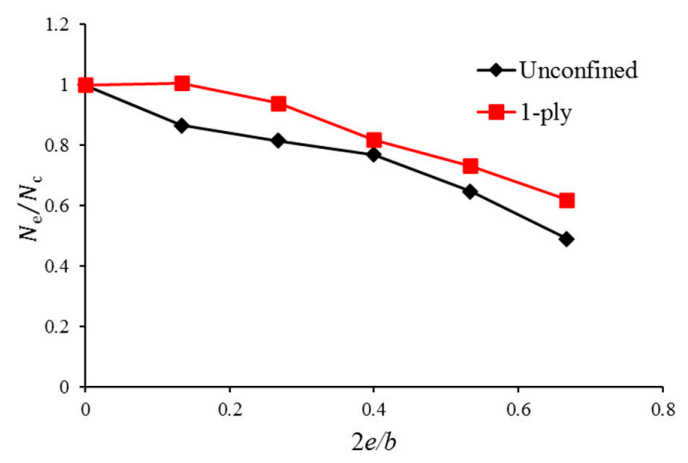

(c) $r=45 \mathrm{~mm}$

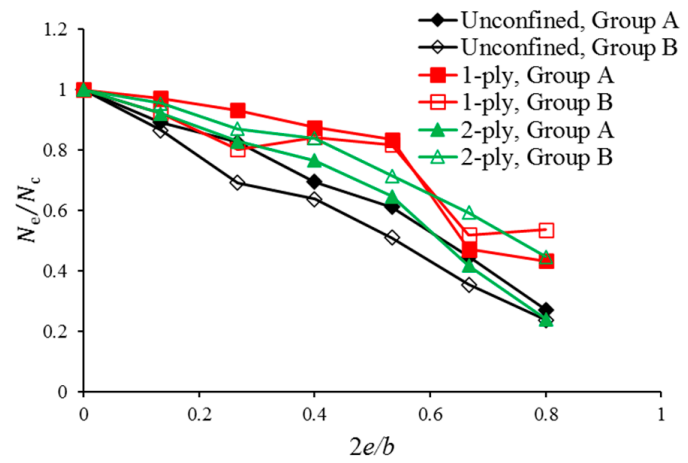

(b) $r=30 \mathrm{~mm}$

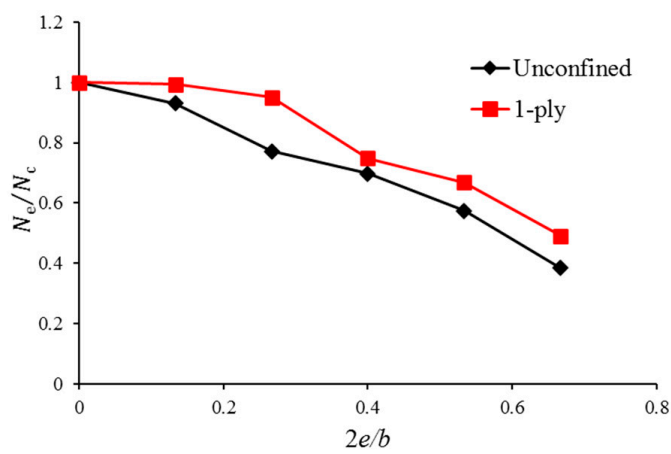

(d) $r=60 \mathrm{~mm}$

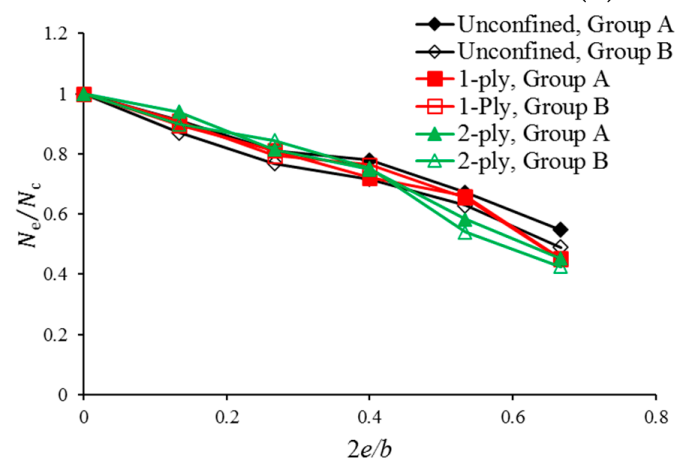

(e) $r=75 \mathrm{~mm}[30]$

Figure 6. Effect of the load eccentricity on $N_{e} / N_{c}$ : (a) $r=15 \mathrm{~mm}$; (b) $r=30 \mathrm{~mm}$; (c) $r=45 \mathrm{~mm}$; (d) $r=60 \mathrm{~mm}$; (e) $r=75 \mathrm{~mm}$ [30].

The contribution from the FRP confinement can be further investigated by studying the effect of the load eccentricity on $N_{e} / N_{f 0}$, where $N_{f 0}$ is the axial strength for unconfined concrete with the same load eccentricity as that of $N_{e}$. The comparison results are shown in Figure 7. The confinement efficiency can be easily revealed for the term $N_{e} / N_{f 0}$. A high value of $N_{e} / N_{f 0}$ represents a higher efficiency due to the FRP confinement because this ratio represents the strength enhancement by the FRP confinement. For most FRP-confined square concrete specimens, it can be found in Figure 7 that the value of $N_{e} / N_{f 0}$ increases when the load eccentricity increases. However, the increasing load eccentricity decreases the confinement efficiency for FRP-confined circular concrete specimens. This is reasonable because the circular section has less compressive area than that of square columns for a fixed load eccentricity or natural axis. This trend is more significant for a large eccentricity because of the small height of the natural axis. 


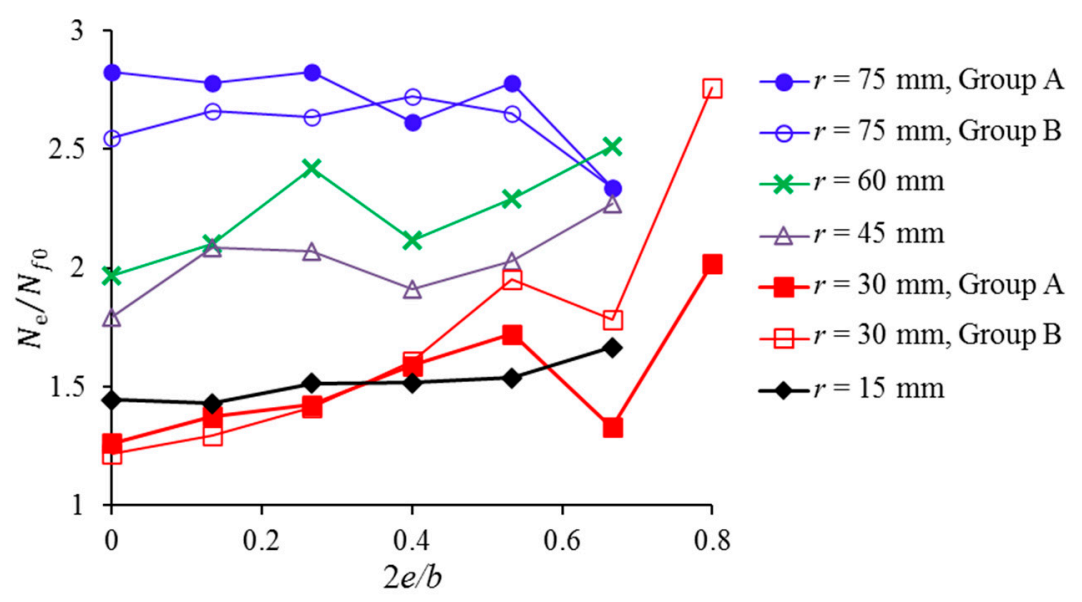

(a) Specimens with 1-ply FRP confinement.

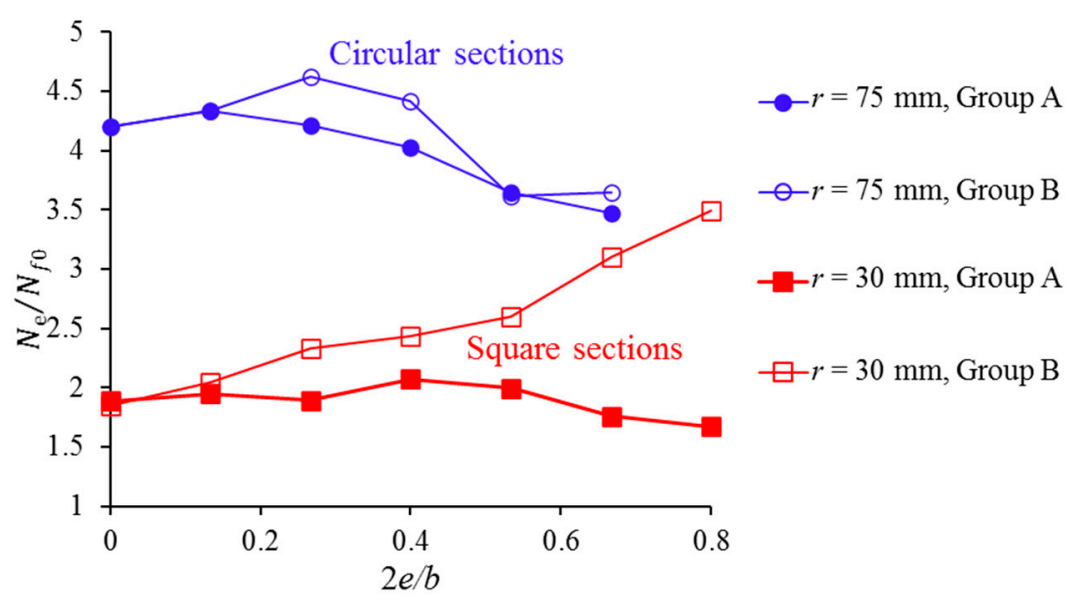

(b) Specimens with 2-ply FRP confinement

Figure 7. Effect of the load eccentricity on $N_{e} / N_{f 0}$ : (a) Specimens with 1-ply FRP confinement; (b) Specimens with 2-ply FRP confinement.

\subsection{Effect of the Corner Radius}

When $2 e / b=0$, which means the concrete is under concentric loading, a greater corner radius can result in a higher value of $N_{e} / N_{f 0}$, as shown in Figure 7 . An exception to this trend is the case where $r=15 \mathrm{~mm}$ (Figure 7a). This is because the specimens with $r=15 \mathrm{~mm}$ have the lowest unconfined concrete strength, as shown in Table 1. The lower concrete strength leads to a higher confinement effect for the fixed FRP wrapping layers.

The reduction in the confinement effectiveness due to the corner radius of an FRP-confined square-shaped column under concentric loading can be accounted for with an accurate shape factor $k_{s}[24-26]$ as:

$$
k_{s}=(2 r / b)^{0.72}
$$

However, Equation (2) was proposed for the ultimate strength of the stress-strain relationship of FRP-confined concrete. Jiang et al. [55] extended and summarized a general relationship for the influence of the corner radius on the structural indexes (e.g., axial strength and plastic hinge length) of FRP-confined concrete structures, as shown in Equation (3).

$$
S_{s f} / S_{s 0}=1+(2 r / b)^{0.72}\left(S_{c f} / S_{c 0}-1\right)
$$


where $S_{s f}$ and $S_{s 0}$ are the structural indexes of FRP-confined square concrete and unconfined square concrete, respectively; $S_{c f}$ and $S_{c 0}$ are the performances of FRP-confined circular concrete and unconfined circular concrete, respectively. If Equation (3) is applied to determine the axial strength of FRP confined concrete under eccentric loading, Equation (3) can be written as:

$$
N_{e} / N_{f 0}=1+(2 r / b)^{0.72}\left(N_{c-f} / N_{c-0}-1\right)
$$

where $N_{c-f}$ and $N_{c-0}$ are the $N_{e}$ and $N_{f 0}$ values for $2 r / b=1$ (i.e., circular section), respectively.

The $N_{e} / N_{f 0}$ values for the various corner radii with a fixed number of FRP layers are plotted in Figure 8. It can be found from Figure 8 that the relationship for Equation (4) can basically describe the effect of the corner radius for FRP-confined concrete subjected to eccentric loading. Here, $N_{c-f} / N_{c-0}$ in Equation (4) takes the average test values in Figure 8 in the analysis. This finding provides a foundation for developing an eccentricity-based stress-strain model of FRP-confined square columns, which requires future study.

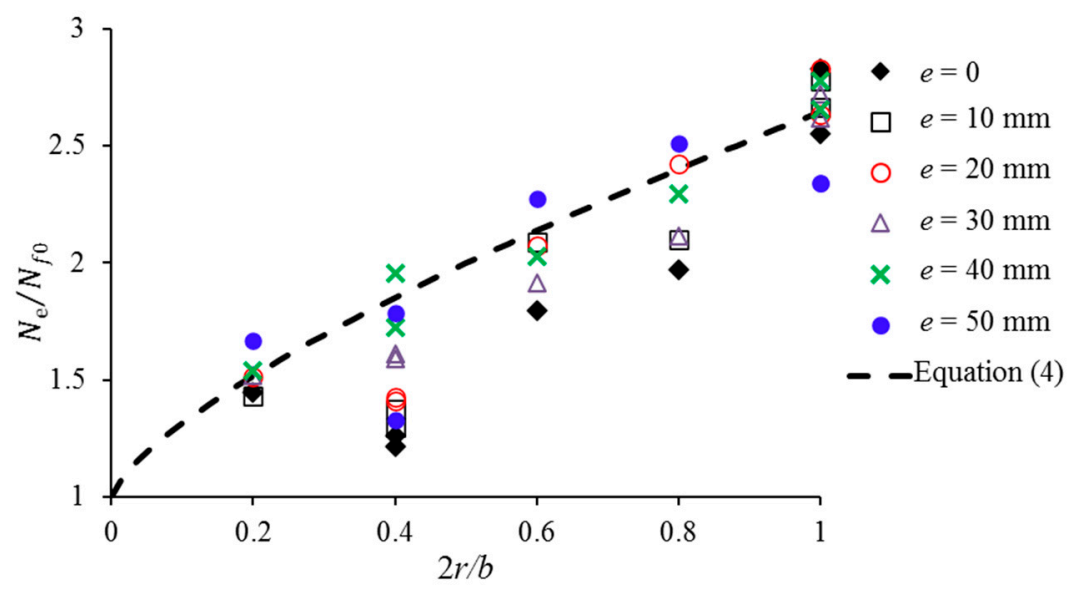

(a) 1-ply FRP jacketing

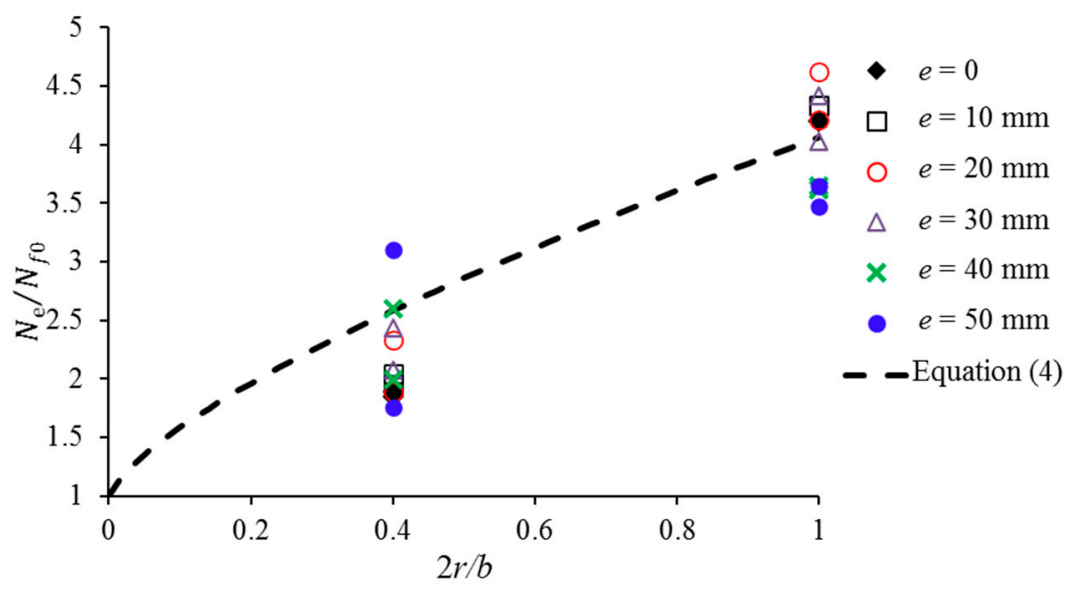

(b) 2-ply FRP jacketing

Figure 8. Effect of the corner radius on $N_{e} / N_{f 0}$ : (a) 1-ply FRP jacketing; (b) 2-ply FRP jacketing.

\section{Conclusions}

The compression tests on a total of 78 FRP-confined square concrete columns subjected to eccentric loading were reported in this work. The degradation of the axial load capacity due to the load eccentricity was investigated. After analyzing the test results, the following conclusion can be drawn. 
(1) When the load eccentricity is small (e.g., $10 \mathrm{~mm}$ or $2 e / b=0.13$ ), the axial strength reduction degree is limited and is occasionally close to 0 . However, when the load eccentricity increases, the decrease in the axial strength is more significant.

(2) FRP confinement can reduce the axial strength degradation compared with that of unconfined concrete specimens. While different confinement levels (i.e., 1 layer and 2 layers) do not have a significant influence on the strength degradation.

(3) For FRP-confined square concrete specimens, the strength enhancement due to FRP confinement increases with increasing load eccentricity. However, the increasing load eccentricity decreases the confinement efficiency for FRP-confined circular concrete specimens. This is because the circular section has a much less compressive area than that of square columns for a fixed natural axis.

(4) The relationship between the structural behavior of FRP-confined square columns and their corner radii (Equation (4)) can basically describe the effect of the corner radius on the axial strength of FRP-confined concrete subjected to eccentric loading.

Author Contributions: Conceptualization, Y.-F.W.; methodology, C.J. and Y.-F.W.; validation, C.J.; formal analysis, C.J.; investigation, C.J.; resources, Y.-F.W.; data curation, C.J.; writing-original draft preparation, C.J.; writing-review and editing, Y.-F.W.; visualization, C.J.; supervision, Y.-F.W.; project administration, Y.-F.W.; funding acquisition, Y.-F.W. All authors have read and agreed to the published version of the manuscript.

Funding: This research was funded by the Victoria-Jiangsu Program for Technology and Innovation R\&D, from the Department of Economic Development, Jobs, Transport and Resources, the state of Victoria, Australia, and the Australian Research Council (DP200100631).

Acknowledgments: The experimental tests in this work were undertaken by the former $\mathrm{Ph}$. D. student Leiming Wang, and his contribution is acknowledged.

Conflicts of Interest: The authors declare no conflict of interest.

\section{Nomenclature}

$b \quad$ length of the side for square cross-sections and the diameter for circular sections

$d$ depth of the cross-section, $=\mathrm{b}$ for square cross-sections

$e \quad$ load eccentricity

$f_{c o} \quad$ unconfined concrete strength

$h \quad$ height of the specimens

$k_{s} \quad$ shape factor for the corner radius, $=(2 r / b)^{0.72}$

$N_{c} \quad$ axial strength for the concentrically loaded specimens

$N_{c 0} \quad$ axial strength for the concentrically loaded unconfined concrete specimen.

$N_{c-0} \quad N_{f 0}$ value for $2 r / b=1$ (i.e., circular section)

$N_{c-f} \quad N_{e}$ value for $2 r / b=1$ (i.e., circular section)

$N_{e} \quad$ axial load capacity (or axial strength) of short columns

$N_{f 0} \quad$ axial strength for the unconfined concrete specimens

$r \quad$ corner radius

$S_{c 0} \quad$ structural index of the unconfined circular concrete

$S_{c f} \quad$ structural index of the FRP-confined circular concrete

$S_{s 0} \quad$ structural index of the unconfined square concrete

$S_{s f} \quad$ structural index of the FRP-confined square concrete

$\rho \quad$ corner radius ratio, $=2 r / b$

\section{References}

1. Wu, Y.F.; Jiang, C.; Yuan, F.; Zhao, X.M.; Wang, J.S. Labor and Cost Efficient Construction Method for Retrofitting RC Columns with FRP; Construction Industry Council: Hong Kong, China, 2020.

2. Keshtegar, B.; Gholampour, A.; Ozbakkaloglu, T.; Zhu, S.P.; Trung, N.T. Reliability analysis of FRP-confined concrete at ultimate using conjugate search direction method. Polymers 2020, 12, 707. [CrossRef] [PubMed]

3. Zhou, Y.; Hu, J.; Li, M.; Sui, L.; Xing, F. FRP-confined recycled coarse aggregate concrete: Experimental investigation and model comparison. Polymers 2016, 8, 375. [CrossRef] [PubMed] 
4. Li, P.D.; Wu, Y.F.; Zhou, Y.; Xing, F. Stress-strain model for FRP-confined concrete subject to arbitrary load path. Compos. Part B Eng. 2019, 163, 9-25. [CrossRef]

5. Zeng, J.J.; Guo, Y.; Li, L.; Chen, W. Behavior and three-dimensional finite element modeling of circular concrete columns partially wrapped with FRP strips. Polymers 2018, 10, 253. [CrossRef]

6. Feng, P.; Cheng, S.; Bai, Y.; Ye, L. Mechanical behavior of concrete-filled square steel tube with FRP-confined concrete core subjected to axial compression. Compos. Struct. 2015, 123, 312-324. [CrossRef]

7. Jiang, C.; Yuan, F.; Wu, Y.F.; Zhao, X.M. Effect of interfacial bond on plastic hinge length of FRP-confined RC columns. J. Compos. Constr. 2019, 23, 04019007. [CrossRef]

8. Jiang, C.; Wu, Y.F.; Dai, M.J. Degradation of steel-to-concrete bond due to corrosion. Constr. Build. Mater. 2018, 158, 1073-1080. [CrossRef]

9. Lin, H.; Zhao, Y.; Ozbolt, J.; Feng, P.; Jiang, C.; Eligehausen, R. Analytical model for the bond stress-slip relationship of deformed bars in normal strength concrete. Constr. Build. Mater. 2019, 198, 570-586. [CrossRef]

10. Idris, Y.; Ozbakkaloglu, T. Seismic behavior of high-strength concrete-filled FRP tube columns. J. Compos. Constr. 2013, 17, 04013013. [CrossRef]

11. Mohamed, H.M.; Masmoudi, R. Axial load capacity of concrete-filled FRP tube columns: Experimental versus theoretical predictions. J. Compos. Constr. 2010, 14, 231-243. [CrossRef]

12. Huang, L.; Sun, X.; Yan, L.; Zhu, D. Compressive behavior of concrete confined with GFRP tubes and steel spirals. Polymers 2015, 7, 851-875. [CrossRef]

13. Lam, L.; Teng, J.G. Design-oriented stress-strain model for FRP-confined concrete. Constr. Build. Mater. 2003, 17, 471-489. [CrossRef]

14. Ozbakkaloglu, T.; Gholampour, A.; Lim, J.C. Damage-plasticity model for FRP-confined normal-strength and high-strength concrete. J. Compos. Constr. 2016, 20, 04016053. [CrossRef]

15. Zeng, J.J.; Ye, Y.Y.; Guo, Y.C.; Lv, J.F.; Ouyang, Y.; Jiang, C. PET FRP-concrete-high strength steel hybrid solid columns with strain-hardening and ductile performance: Cyclic axial compressive behavior. Compos. Part $B$ Eng. 2020, 190, 107903. [CrossRef]

16. Jiang, C.; Wu, Y.F.; Jiang, J.F. Effect of aggregate size on stress-strain behavior of concrete confined by fiber composites. Compos. Struct. 2017, 168, 851-862. [CrossRef]

17. Ozbakkaloglu, T.; Vincent, T. Axial compressive behavior of circular high-strength concrete-filled FRP tubes. J. Compos. Constr. 2014, 18, 04013037. [CrossRef]

18. Pham, T.M.; Hadi, M.N. Confinement model for FRP confined normal-and high-strength concrete circular columns. Constr. Build. Mater. 2014, 69, 83-90. [CrossRef]

19. Zhou, A.; Qin, R.; Chow, C.L.; Lau, D. Structural performance of FRP confined seawater concrete columns under chloride environment. Compos. Struct. 2019, 216, 12-19. [CrossRef]

20. Wu, G.; Wu, Z.S.; Lü, Z.T. Design-oriented stress-strain model for concrete prisms confined with FRP composites. Constr. Build. Mater. 2007, 21, 1107-1121. [CrossRef]

21. Al-Salloum, Y.A. Influence of edge sharpness on the strength of square concrete columns confined with FRP composite laminates. Compos. Part B Eng. 2007, 38, 640-650. [CrossRef]

22. Ozbakkaloglu, T. Axial compressive behavior of square and rectangular high-strength concrete-filled FRP tubes. J. Compos. Constr. 2013, 17, 151-161. [CrossRef]

23. Lam, L.; Teng, J.G. Design-oriented stress-strain model for FRP-confined concrete in rectangular columns. J. Reinf. Plast. Compos. 2003, 22, 1149-1186. [CrossRef]

24. Wu, Y.F.; Wei, Y.Y. Effect of cross-sectional aspect ratio on the strength of CFRP-confined rectangular concrete columns. Eng. Struct. 2010, 32, 32-45. [CrossRef]

25. Wei, Y.Y.; Wu, Y.F. Unified stress-strain model of concrete for FRP-confined columns. Constr. Build. Mater. 2012, 26, 381-392. [CrossRef]

26. Wu, Y.F.; Wang, L.M. Unified strength model for square and circular concrete columns confined by external jacket. J. Struct. Eng. 2009, 135, 253-261. [CrossRef]

27. Cao, Y.G.; Jiang, C.; Wu, Y.F. Cross-sectional unification on the stress-strain model of concrete subjected to high passive confinement by fiber-reinforced polymer. Polymers 2016, 8, 186. [CrossRef]

28. El Maaddawy, T. Strengthening of eccentrically loaded reinforced concrete columns with fiber-reinforced polymer wrapping system: Experimental investigation and analytical modeling. J. Compos. Constr. 2009, 13, 13-24. [CrossRef] 
29. Hu, B.; Wang, J.G.; Li, G.Q. Numerical simulation and strength models of FRP-wrapped reinforced concrete columns under eccentric loading. Constr. Build. Mater. 2011, 25, 2751-2763. [CrossRef]

30. Wu, Y.F.; Jiang, C. Effect of load eccentricity on the stress-strain relationship of FRP-confined concrete columns. Compos. Struct. 2013, 98, 228-241. [CrossRef]

31. Lin, G.; Teng, J.G. Three-dimensional finite-element analysis of FRP-confined circular concrete columns under eccentric loading. J. Compos. Constr. 2017, 21, 04017003. [CrossRef]

32. Li, J.; Hadi, M.N.S. Behaviour of externally confined high-strength concrete columns under eccentric loading. Compos. Struct. 2003, 62, 145-153. [CrossRef]

33. Fam, A.; Flisak, B.; Rizkalla, S. Experimental and analytical modeling of concrete-filled fiber-reinforced polymer tubes subjected to combined bending and axial loads. ACI Struct. J. 2003, 100, 499-509.

34. Tao, Z.; Teng, J.G.; Han, L.H.; Lam, L. Experimental behaviour of FRP-confined slender RC columns under eccentric loading. In Proceedings of the 2nd International Conference on Advanced Polymer Composites for Structural Applications in Construction, Surrey, UK, 20-22 April 2004; pp. 203-212.

35. Hadi, M.N.S. Comparative study of eccentrically loaded FRP wrapped columns. Compos. Struct. 2006, 74, 127-135. [CrossRef]

36. Hadi, M.N.S. Behaviour of FRP wrapped normal strength concrete columns under eccentric loading. Compos. Struct. 2006, 72, 503-511. [CrossRef]

37. Hadi, M.N.S. Behaviour of FRP strengthened concrete columns under eccentric compression loading. Compos. Struct. 2007, 77, 92-96. [CrossRef]

38. Hadi, M.N.S. The behaviour of FRP wrapped HSC columns under different eccentric loads. Compos. Struct. 2007, 78, 560-566. [CrossRef]

39. Hadi, M.N.S. Behaviour of eccentric loading of FRP confined fibre steel reinforced concrete columns. Constr. Build. Mater. 2009, 23, 1102-1108. [CrossRef]

40. Bisby, L.; Ranger, M. Axial-flexural interaction in circular FRP-confined reinforced concrete columns. Constr. Build. Mater. 2010, 24, 1672-1681. [CrossRef]

41. Cao, Y.; Wu, Y.F.; Jiang, C. Stress-strain relationship of FRP confined concrete columns under combined axial load and bending moment. Compos. Part B Eng. 2018, 134, 207-217. [CrossRef]

42. Chaallal, O.; Shahawy, M. Performance of fiber-reinforced polymer-wrapped reinforced concrete column under combined axial-flexural loading. ACI Struct. J. 2000, 97, 659-668.

43. El Maaddawy, T. Behavior of corrosion-damaged RC columns wrapped with FRP under combined flexural and axial loading. Cem. Concr. Compos. 2008, 30, 524-534. [CrossRef]

44. El Maaddawy, T. Post-repair performance of eccentrically loaded RC columns wrapped with CFRP composites. Cem. Concr. Compos. 2008, 30, 822-830. [CrossRef]

45. Elwan, S.K.; Rashed, A.S. Experimental behavior of eccentrically loaded R.C. short columns strengthened using GFRP wrapping. Struct. Eng. Mech. 2011, 39, 207-221. [CrossRef]

46. Hadi, M.N.S.; Widiarsa, I.B.R. Axial and flexural performance of square RC columns wrapped with CFRP under eccentric loading. J. Compos. Constr. 2012, 16, 640-649. [CrossRef]

47. Hajsadeghi, M.; Alaee, F.J. Numerical analysis of rectangular reinforced concrete columns confined with FRP jacket under eccentric loading. In Proceedings of the 5th International Conference on FRP Composites in Civil Engineering, Beijing, China, 27-29 September 2010; pp. 658-661.

48. Quiertant, M.; Clement, J.L. Behavior of RC columns strengthened with different CFRP systems under eccentric loading. Constr. Build. Mater. 2011, 25, 452-460. [CrossRef]

49. Sadeghian, P.; Rahai, A.R.; Ehsani, M.R. Experimental study of rectangular RC columns strengthened with CFRP composites under eccentric loading. J. Compos. Constr. 2010, 14, 443-450. [CrossRef]

50. Shaheen, E.; Shrive, N.G. Sprayed glass fibre reinforced polymer masonry columns under concentric and eccentric loading. Can. J. Civ. Eng. 2007, 34, 1495-1505. [CrossRef]

51. Csuka, B.; Kollár, L.P. FRP-confined circular columns subjected to eccentric loading. J. Reinf. Plast. Composit. 2011, 30, 1167-1178. [CrossRef]

52. Li, P.; Sui, L.; Xing, F.; Li, M.; Zhou, Y.; Wu, Y.F. Stress-strain relation of FRP-confined predamaged concrete prisms with square sections of different corner radii subjected to monotonic axial compression. J. Compos. Constr. 2019, 23, 04019001. [CrossRef] 
53. ASTM Standard Test Method for Tensile Properties of Polymer Matrix Composite Materials; D3039/D3039M-95; Annual Book of ASTM Standards: Philadelphia, PA, USA, 1995.

54. Wei, Y.; Jiang, C.; Wu, Y.F. Confinement effectiveness of circular concrete-filled steel tubular columns under axial compression. J. Constr. Steel Res. 2019, 158, 15-27. [CrossRef]

55. Jiang, C.; Wu, Y.F.; Wu, G. Plastic hinge length of FRP-confined square RC columns. J. Compos. Constr. 2014, 18, 04014003. [CrossRef]

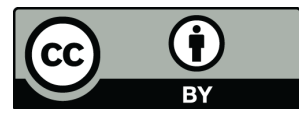

(C) 2020 by the authors. Licensee MDPI, Basel, Switzerland. This article is an open access article distributed under the terms and conditions of the Creative Commons Attribution (CC BY) license (http://creativecommons.org/licenses/by/4.0/). 